Сања П. Веселиновић

Универзитет у Новом Саду

Филозофски факултет

veselinovic3223@gmail.com doi: $10.19090 /$ zjik.2018.75-86

UDK 821.163.41.09 Ignjatović J.

оригинални научни рад

\title{
РАБЛЕОВСКИ НИЗОВИ ЈЕЛА И ПИЋА У РОМАНУ ЈАКОВА ИГЊАТОВИЋА МИЛАН НАРАНЦИТ
}

САЖЕТАК: У раду се анализира функционалност раблеовских низова јела и пића у наративној структури романа српског реализма Милан Нараниић. Истражено је на који начин храна и пиће учествују у карактеризацији ликова и обликују реалистичну атмосферу дела, као и коју улогу имају у формирању слике друштва с краја 19. века и почетком 20. века. Циљ рада је утврђивање замена које се одвијају на позадинском семантичком плану дела, а које показују да се на место отровне огорчености поставља „здрав смех”, а на место лажног аскетизма весела гозба. Указује се, међутим, и на разлике које постоје између веселе гозбе код Раблеа и код Јакова Игњатовића, као и на начин на који овакве разлике доприносе скицирању лика модерног антијунака, Милана Наранџића. На основу примера из романа приказује се пишчево варирање приказа раблеовских низова и њиховог коришћења у функцији основне идеје дела. Резултати рада показују да је Јаков Игњатовић вештом инкорпорацијом гозбених слика у фабулативну структуру свог дела, допринео његовом укључивању у шири контекст српске и европске књижевности.

Кључне речи: гозбене слике, гротеска, храна и пиће, Франсоа Рабле, Михаил Бахтин

Раблеовским низовима јела и пића први се подробније бавио Михаил Бахтин у својој студији Стваралаштво Франсоа Раблеа и народна култура средњега века и ренесансе. У четвртом поглављу под називом „Гозбене слике код Раблеа", Бахтин истиче значајну улогу коју такве слике заузимају у целом Раблеовом делу Гаргантуа и Пантагруел. Како наводи, „готово да нема стране без тих слика, макар у виду метафора или епитета позајмљених из области једења и пијења" (Бахтин 1978: 296). Специфичан семантички потенцијал који произилази из раблеовских низова јела и пића недовољно је истражен када су у питању дела српских реалиста. Управо у њиховим делима ови низови најчешће се могу пронаћи, при чему добијају нове улоге, а неке од старих мењају или их у потпуности губе. Чини се, ипак, да су таква истраживања до сада била на маргини наше књижевне науке, иако се поједини радови баве, на пример, кулинарском лексиком у роману Поп Ћира u non Спира Стевана Сремца (Петровачки; Недељков 2011), односно кухињом Сремчевих јунака и 
њеном везом са Српским куварем Јеротеја Драгановића (Иконић 2013). Када је у питању тумачење Михаила Бахтина, истиче се нераскидива повезаност гозбених слика са празницима, са смеховним комадима, гротескним телом, као и тенденција гозбе ка изобиљу и свенародности (в. Бахтин 1978: 297). Међутим, за дела српских реалиста значајнија је суштинска повезаност таквих слика „с речју, с мудрим разговором, с веселом истином” (Бахтин 1987: 297). Функције гозбених слика у средњовековној традицији коју Бахтин истражује биле су ослобађање речи и обезбеђивање веселог и смелог тона читавом делу (в. Бахтин 1987: 312-313). „Весео и смео тон” свакако је присутан и у делима српских реалиста, где се у атмосфери гозбе и тону разговора након јела, исказује слободна и отворена истина - она коју су српски реалисти, сваки на свој специфичан начин, уобличавали у хумор, излагали подсмеху, или је стављали под, више или мање експлицитну, сатиричку оштрицу.

С друге стране, једење се у најстаријем систему слика појављивало као „последња, победоносна фаза рада” и често је представљало „сав радни процес у његовој укупности" (Бахтин 1978: 298). И у роману Гаргантуа и Пантагруел велике гозбе наступале су иза великих заједничких радова и након значајних борби и бојева. Овакав аспект гозбених слика у роману Милан Наранцић Јакова Игњатовића готово у потпуности изостаје, што није без свог значењског потенцијала. На појединачним примерима биће детаљно анализирано на који начин низови јела и пића ипак чувају своју универзалност, као и своју суштинску повезаност са животом, победом која се слави, али и препородом. Биће приказано, такође, и како се као наличје прославе заједничког радног или борбеног тријумфа у делу Игњатовића једење и пијење најчешће појављује у облику индивидуалног уживања, и ситости егоистичног човека. Многострукост видова и улога коју низови хране и пића имају у анализираном делу понекада превазилази предзнак „раблеовски”. Какав је допринос таквих гозбених слика српском реализму, биће основна тема овог рада.

\section{1. СЈЕДИЬАВАњЕ ЧИНОМ ЈЕДЕЬА И ПИЈЕЬА И ИНДИВИДУАЛНО ЗАДОВОљЕЬЕ}

Већ прва реченица романа Јакова Игњатовића имплицира изузетан значај хране и пића за његовог јунака: „Милан Наранџић често је своје пријатеље на ручак и вечеру звао и с њима је при добром јелу и вину веселе часе проводио" (Игњатовић 1969: 35). Јунак романа - или антијунак - о свом животу говори на захтев пријатеља, а „Милан доиста за удовољити их, више 
вечера приповедао им је при чаши вина ил' чаја" (Игњатовић 1969: 35). На тај начин се у овом роману управо у пријатној и присној атмосфери заједничког једења и пијења отвара „дневник једног живота, или, још пре, неколико здружених живота - Милана Наранџића, Бранка Орлића, њихових љубави, њихових жена, њихових пријатеља" (Кашанин 2004: 96). На самом почетку, говорећи о свом имену, јунак открива особину која га обележава током целог романа, а која на значајан начин гради и објашњава причу о његовој будућности. Када истакне како је његово име „срећно” не само зато што се допада женама, него и зато што га може двоструко употребљавати (,у простијем друштву Милан, у ноблијем - Емил” [Игњатовић 1969: 36]), Милан Наранџић открива изузетну способност социјалне мимикрије. Међутим, наведени пример открива и специфичан начин на који аутор представља особине свог јунака: начин који га чини колико подложним читаочевом оштром критичком суду, толико и пријемчивим за његов укус. Милан Наранџић приповеда сам о себи, при чему је већ у основи немогуће одвојити субјективно од објективног у његовом казивању. Аутор пак дозвољава читаоцу да уочи управо несразмеру између субјективог и објективног, што изазива хуморне ефекте.

Када јунак говори о свом детињству, инфантилна безазленост у његовом виђењу сопствене личности додатно је интензивирана. Хумор који одатле произилази посебно је приметан у деловима када јунак говори о свом односу према храни. Разлог зашто он представља прво мати, па потом оца, сем зато што га је она родила, јесте тај што му је она често „у детињству крадом, да отац не види, јести давала; отац пак често ми је апетит са дизгом ил' рифом покварио" (Игњатовић 1969: 37). Роман, посебно његов почетак, засићен је оваквим деловима у којима јунак истиче своју незајажљиву глад. У свом школском животу не сматра важним ништа до онога што га је „највећма мучило", а то је чињеница да је константно био гладан:

Код куће, истина, имао сам доста јести, лебац је истина био црн, ал’ добар; но све је то мени мало било. Мати ми је често додавала крадом чанчић резанаца са сиром; наравно, морао сам брзо јести да ме отац не уфати; не једанпут гушећи се са резанци, нашао ме отац и песницом по врату помагао им клизати се. Но до једног сата опет сам био гладан. Моји другови знали су то и звали ме прождрљивим. Ако ујутру у школи, пре нег што ће учитељ доћи, моји другови, који свој фруштук не могу да изеду, а они са мном у погодбу, па ми 
даду по шест до десет палица, па тек легнем за по кифле драговољно (Игњатовић 1969: 37-38).

За апетите Милана Наранџића хране никада није било довољно, иако сам истиче да његова породица никада није гладовала, а да је отац као шнајдерски мајстор радио марљиво целога живота. Прождрљивост Миланова у раном узрасту хипертрофирана је до граница где ни батине не представљају препреку за задовољење његовог доминантног нагона. Бесконачна глад један је од карактеристичних раблеовских мотива. У чину једења, границе између тела и света превазилазе се и коначно губе, док тело наставља да расте науштрб света (в. Бахтин 1987: 299). Пантагруеловска глад Милана Наранџића у детињству, као и труд да се она утоли упркос многим осујећењима, представљају његов први снажан пробој ка свету. Његови покушаји у будућности да начини пробој и заузме себи место у свету постају све амбициознији. Милан уводи у причу о свом животу и своје пријатеље, а као најбољег наводи Бранка Орлића. Њихов однос, али и Бранков карактер, открива се на занимљив начин кроз још једну у низу анегдота у којима храна игра значајну улогу: „Сваки дан ми је донео у школу на фруштук једну кифлу, без да је изискивао да ми удари шест; штавише, бранио ме против нападача када се случило да сам најпре изео земичку, а нисам хтео лећи; он је сваког слабијег против јачег бранио, па и мене ма против петорице бранио је” (Игњатовић 1969: 39). Како и сам Милан Нараџић истиче, Бранков живот био је „свезан” са његовим, због чега прича о његовом животу добија једнаку важност пред слушаоцима и читаоцима. Васпитање које је добијао од стране имућног, али строгог тутора, било је спартанско, те је у извесној мери аскетски однос према храни још један у низу чиниоца који су обликовали Бранков карактер. „Фруштука и ужине нема, само ручак и вечеру”, напомиње Милан у приповести о Бранковом детињству уз тутора-особењака (Игњатовић 1969: 44). Међутим, док је Бранков тутор имао настојање да од Бранка учини чврстог и поштеног човека, који није ласкавац ни улизица, Милан већ у детињству живи по другачијим принципима. Сем понизности пред учитељем, неговао је највећу послушност пред куварицом. Да се није устезао од ласкања и улизивања како би достигао неки циљ, говори и следећа реченица: „Она се само звала виршофтерком, а ја сам ју звао милостивом госпођом, па онда јести доста" (Игњатовић 1969: 45). Поново је ситост у очима младог Милана представљала циљ пред којим су сва средства оправдана. Након очеве смрти, у новој кући код господина К. примљен је добро, међутим, његова стара болест, глад, не престаје да га мучи. Иако је свега било довољно, а понекада би због 
послушности добио и већу порцију јела него остали, никада не успева да се засити: „Тужили су се да сам изем толико 'леба као сви други” (Игњатовић 1969: 42).

Делови романа о ђачком животу у Пешти одликују се посебном лепотом јер из њих неодољиво избија снага младости и ведрине. „То је особити неки живот, особита појезија живота" (Игњатовић 1969: 53), усхићено проговара аутор кроз лик Милана Наранџића. За разлику од ранијих и каснијих година његовог живота, у овим годинама доминанту улогу у односу на храну преузима пиће. Градске кафане и пиваре представљају најпосећенија места пештанских ђака. Друштво које је Милану било најмилије, а којем је припадао и Бранко, назива се друштвом „браденбургера”. Сем што истиче да су то били они који су свуда радо ишли, Милан Наранџић описује браденбургера и као онога ко се „од пића није ни најмање затезао, било то вино ил' пиво” (Игњатовић 1969: 63). О веселости слика у којима су описани доживљаји овог друштва, најбоље говори исказ самог Нараџића: „Кад се ђаци каковом већом приликом при чаши вина састану, онда ретко кад да какова комендија не испадне" (Игњатовић 1969: 64). Једна од главних одлика карневала и гозбених слика уопште, јесте та да у гозби учествују сви, и она се у роману Милан Нараниић највише испољава управо у деловима који описују ђачки живот у Пешти. Нико не може и не сме бити изостављен, без обзира на свој углед, друштвену функцију или положај. Једна од најупечатљивијих кафанских сцена је она у којој учествује и формундер, тутор у општини. У ђачкој атмосфери пијења без граница, формундер варошице К. се напија. Аутор истиче да је његово занимање у једној вароши „најглавније пургерско званије” (Игњатовић 1969: 64). То, пак, веселе и припите ђаке не спречава да уснулог формундера положе на земљу као мртваца, запале му свеће, и одрже му бдење „у духу parodia sacra” (Максимовић 2003: 122). Карневалска инверзија профаног и сакралног, и веселог и тужног, у овој сцени достиже свој врхунац. Формундер завршава на столу са којег му ђаци не дозвољавају да сиђе: „Он тре очи, 'оће ногом доле, ал' ни разговора, но Цигани свирају, а њему уклопе бутелију ликера, под кондицијом да испије бутелију. Најпре неће, после мора, и то тако славан човек - формунд једне привилегирате вароши. Једанпут, двапут, па јошт једанпут, па празна бутелија. Онда га скину, па удри 
с њим у францес" (Игњатовић 1969: 66). ${ }^{1}$ Начин на који су овакве сцене описане и организоване у роману Милан Наранщић, указују не само на значај пића и хране код Игњатовића, него и на изузетне сценографске способности писца. Како Милан Кашанин примећује, код Игњатовића је напоредо са вештим портретисањем и „бележење како се оне крећу, говоре, дочекују, испраћају, играју, опијају се (курзив С. В.), варају, претварају се, краду, парниче се" (Кашанин 2004: 91).

Док Бранко доживљава прва заљубљивања, Милан се, као и током целог романа, више бави практичним стварима, те тако он договара квартире и за Бранка и за себе. Поново храна и пиће играју велику улогу у једном домаћинству: „Госа често нас звао на вечеру. Било дост' са сиром резанаца, а ми смо опет за његову љубов не једанпут морали ићи Код пужа на халбсајтел” (Игњатовић 1969: 67). Резанци представљају једно од омиљених јела Милана Наранџића. Када сретне своју стару пријатељицу Лауру, она га на ту, често неумерену љубав, подсећа: „Знате кад сте изели велики чанац резанаца и јошт поред тога две роспрадле, у опкаду са Татомиром?” (Игњатовић 1969: 68). Како му се такво подсећање није допало, он јој одговара: „Видите, фрајлице, сад Вам опет сасвим мало једем; нарав ми се преокренула; сад да ми је мало фазана, дивљачине какве, па компота" (Игњатовић 1969: 68). Миланова нарав ce, у складу са уобичајеним структурирањем ликова у делима Јакова Игњатовића, није изменила, али се прилагодила конвенцијама друштва. Његова глад више није детиње и раблеовски бесконачна, али је константно присутна, и сада подељена на више материјалних циљева. Главни Миланов циљ јесте да се богато ожени. Док Бранко Орлић непрестано налази „даме у невољи”, Милан Наранџић покушава да нађе даму са миразом. И један и други упознају жене на својим путовањима, обично у гостима и за богатим трпезама. На једном од својих многобројних заједничких путовања, заустављају се селу К. и уживају у гостопримству свог кмета: „Одма’ чика заповеди да се фруштук преправи, вино донесе. Синовица све то уређује, а поред тога на велику фуруну пази, пече 'лебац, леп као колач, па сад опет за нас снова пламењаче ће

\footnotetext{
${ }^{1}$ Ова сцена у роману Милан Наранцић може се упоредити са сличном сценом у роману Симе Матавуља, Бакоња фра Брне. Ђаци ноћу прелазе зидине манастира како би уживали у дионизијском слављу, а једне од таквих ноћи, они нагоне коњушара Букара да пије: „-- Дајте му одмах да наздрави! - заповиједи Лис. Букар изрече њешто сметено, па нагну бурачом. - Пиј, пиј, колико год мош! - виче му Лис. Након двадесет гутљаја, Букар предуши ваљајући очима” (Матавуљ 1991: 238).
} 
да пече" (Игњатовић 1969: 81). Игњатовић не пропушта да кроз лик Милана Наранџића детаљније наслика трпезу, па тако наводи: „Био је гуљаш са трганчићима, и то подоста. Вино ваљано...” (Игњатовић 1969: 81). На основу оваквих примера којих је у роману много, поменуте функције гозбених слика допуњују се и чињеницом да „све софре Јакова Игњатовића представљају историјат примања страних примеса у српску кухињу од тринаестог до деветнестог века" (Орсић 2012: 36). Сасвим очекивано, највише је јела мађарског порекла, какво је и гулаш, али и немачког, какве су, на пример, роспрадле. Иако нипошто није избирљив у јелу, Наранџић највише цени различите врсте меса, па тако, сем шунке и говедине, у овом домаћинству хвали јагњетину: „Ручка не би већ ни требало, ал’ дође слуга кући, те му се заповеди да закоље једно јагње. Сад ћемо тек да се частимо. Ја добро једем, ником не уступам, а Здравковић пије и за кмета и за перцептора, премда су се ови обоји већ добро угрејали" (Игњатовић 1969: 81). Таква гозба, очекивано, завршава изјавом Милана Наранџића да једино он сем Бранка није пијан, али да му стомак „тек што не пукне” (Игњатовић 1969: 82). Овакво гошћење једно је од оних са којег су се пријатељи враћали носећи торбу пуну шунке, колача, великих чутура вина, и са девојачком цедуљом намењеној Бранку Орлићу на којој пише: „Опомени ме се”.

У роману су, поред јела из страних кухиња, присутна и различита улепшавања изгледа јела, као и начини на који се јело обогаћује зачинима а које није својствено српским навикама. Тај део гозбених слика, међутим, битнији бива домаћицама него самим учесницима гозбе. У другом делу романа, на једном у низу свакодневних одлазака на ручкове и вечере које Милан Наранџић предузима да би се разонодио, он примећује: „После супе госпођа Јелка одма' устане, па изиђе; мењају се тањири, госпођа Јелка говеђину носи, ја и Десић при'ваћамо. 'Опростите што није по француски гарнирано.' Одговарамо, да боље бити не може” (Игњатовић 1969: 201). У овој сцени је, као и у другим које се одвијају у богатијим кућама, присутно опонашање навика преузетих из страних кухиња. Ипак, да би Милан Наранџић добио статус радо примљеног госта код имућнијих фамилија, пре тога је морао постати и сам имућан. Остварење свог циља и велико богатство остварује „захваљујући одсуству било каквих моралних и етичких скрупула” (Ераковић 2016: 7). Он се жени старијом госпођом, а не би било претерано оценити да то чини на превару. Душан Иванић примећује да је сукоб економије и морала у грађанском друштву карактеристичан, а такав мотив издваја и као једну од одлика почетног раздобља реализма: „У протореализму моралност и 
економски успјех су најчешће инконгруентни, али то није оно што се подржава с гледишта ауторског ја (у роману Ј. Игњатовића)" (Иванић 1996: 67). Игњатовић такву суморну слику друштва разведрава низом авантура у које двојица пријатеља упада. И један и други управо кроз разне перипетије откривају своје типске и психолошке карактеристике. Занимљиво је да сам Милан Наранџић, процењујући сопствено и Бранково сналажење у таквим компликованим ситуацијама, доноси судове о себи и њему кроз метафоре хране и пића. Милан је, насупрот свом пријатељу, опрезан и превејан, што доказује и следећим реченицама:

Ja опет, напротив, узео сам си ту максиму да сваког држим за неваљалог, док се не потврди да је ваљан. Ја држим даље: ко тебе лебом, ти њега колачем; ко тебе палицом, ти њега буџом. Бранко ми се смеје. Он кад не удели каквом просјаку, покаје се у другом сокаку, па се враћа да му што да. Он вели да ни њему не пада добро што има, кад види толико њи' без 'леба (Игњатовић 1969: 106).

Као што се у детињству улагивао куварици да би добио више хране, тако се, тражећи будућу жену, улагује госпођама да би постао више цењен: „Ако сам почашћен, а ја фалим како још нисам тако доброг јела јео, како је јуфка од пите фина као тилангле” (Игњатовић 1969: 107). Свестан свог лицемерног понашања, Милан Наранџић на другом месту о себи каже: „Мене ни враг не би скувао" (Игњатовић 1969: 126). Некада би процењивао друге људе чак и директно преко њиховог односа према храни и пићу. За оне који се „издају за високоучене” каже да „не пију, јер су богаљеви” (Игњатовић 1969: 127). Други се, пак, по његовом мишљењу, у већим друштвима претварају да су умерени, „а кад су код куће, ил' код доброг познатог, попију пре вечере и после пет холби вина" (Игњатовић 1969: 127).

Након што Милан Наранџић постане богати удовац, у другом делу романа објављеном три године после првог, 1863. године, приказује се његов живот који добија све особине бећарског живота. Обиље хране и пиће део је његове свакодневице. „Па кад дође ручак, колико ту јела, колико слаткиша, рекао би да си у грофовској кући" (Игњатовић 1969: 195), закључује у једној од посета које чини. Начин на који Милан Наранџић организује свој живот своди се на следеће: „Можемо у једно место на ручак стићи, у друго на вечеру" (Игњатовић 1969: 195). То не чуди имајући у виду гостопримство које добија где год да се појави: „Бациш поглед на пенџер, а оно видиш како слуга 
јури пиле да га ухвати, а слушкиња већ гуску коље. Дође л’ ручак ил' вечера, ту се без женирања једе, пије, пева" (Игњатовић 1969: 197). Управо у таквим околностима сталних путовања и гошћења, Милан Наранџић упознаје занимљиве људе и бећаре као што је и он сам. Један од таквих је и Чика. Он је сличан Милану и по другим склоностима: „Дође вечера. Све масна, папрена, добра јела доносе. Све ми се допадало. Чика је гурман, чека мелшпајз, ал' га не доносе" (Игњатовић 1969: 292). За таквог гурмана, храна постаје и предмет шале, средство које може послужити за задирикивање. Тако Чика задиркује једног од заједничких пријатеља, Мишкића:

- Па шта, зар немаш тестаног јела?

- Нема; мислио сам да га нико не једе радо.

- Зар га ти никад не једеш?

- Никад. Код мене се никад мелшпајз не прави.

- Дакле, не једеш ни пите?

- Ни пите. Кажем ти: никакав мелшпајз.

- А погачице?

- Кад су слане и са чварци', ал' друго ништа.

- Пијеш ли млеко?

- Никад.

- А како с кајмаком?

- Ни да га видим.

- Волеш ли слатко?

- Не, папрено и кисело.

- Но, то је прави браденбургерски реглама (Игњатовић 1969: 294)

Чика је лик који доноси занимљиве закључке о томе како модерно време утиче на храну и справљање хране. Он примећује промене и због њих негодује:

Откако су измислили тај врашки пшорхерт, не можеш више добра јела јести. Још до неколико година, па ће печење на ражњу у митологију спадати; неће нико веровати да се прасе на ражњу испећи може. Па ту су ти сад торте и кохови мегдан одржали. Знам кад сам био млад, па на ручку у каквој масној господарској кући, кад је највећа тракта, није било више од пет јела. Већ шесто се за луксуз држало. Па каква јела! Све ти сланина за вратом расте. А сад? Кад ручаш у каквој средњој кући, три дана имаш грижу. Ти слаткиши и шпархерти здравље и џеп 
утамањују. Ал' код шпархерта не кува газдарица, већ он сам кува (Игњатовић 1969: 296).

Храна тако добија разликовну функцију којом се старије време одваја од оног новијег, од времена у којем се измишљају врашки новитети. Последња реченица незадовољног Чике указује на постепену дехуманизацију чак и таквог чина као што је припрема јела - машина која кува поставља се насупрот жени која кува, при чему се сасвим изостављају било какве добре стране такве иновације као што је шпорет. У данашњем контексту Чикина побуна делује незамисливо, међутим, у контексту романа где низови јела и пића добијају повлашћено место, она представља ехо носталгије за временима где се уживање у храни и пићу високо вредновало, а у појединим тренуцима третирало и као део сакралног чина. Имајући у виду све сличности између Милана Наранџића и Чике, не изненађује што Милан жали након њиховог растанка. Опроштај са њим подстиче га да управо при крају својих путешествија приказаних у роману, контемплира о непостојаности живота и варљивости судбине. Милан Наранџић резимира свој живот сагледавајући контраст између младости која је прошла, и старости која наступа. Однос према храни поново постаје призма кроз коју јунак посматра свет, и свој положај у свету: „Био сам сирома' ђак, глад увек ненаситима, новаца мало; сад, фала богу, свашта доста. Ал' ди је онај стари апетит?” (Игњатовић 1969: 313). У таквом тону жала за младос' завршава други део приповести о Милану Наранџићу.

Како истиче Кашанин, Јаков Игњатовић „ни у ком погледу није био личност уског формата, ни спутане снаге" (Кашанин 2004: 86). То се осећа и у начину на који конструише своје ликове, те његови романи бивају „пуни смелих и слободних људи" (Кашанин 2004: 85). Њихова неспутаност огледа се и у веселости уз коју уживају у јелу и пићу. Међутим, хедонизам Игњатовићевих ликова има и своју мање веселу страну. У осврту на роман Милан Нараниић, због којег се Јаков Игњатовић назива не само репрезентантом реализма у српској књижевности, већ и његовим зачетником, Кашанин тачно примећује да се не зна „да ли је у том роману више веселости или туге" (Кашанин 2004: 96). Оно што се закључује из раскалашности којом Милан Наранџић приступа храни и пићу, али и животу уопште, јесте чињеница да је „сентандрејски мајстор скицирао портрете модерних антихероја врлог новог света, у којем опскурна социјална мимикрија пружа индивидуи много веће шансе за успех од поштовања основних моралних и 
етичких принципа" (Ераковић 2016: 52). Ово промишљање у складу је са улогом коју гозбене слике заузимају у роману Јакова Игњатовића, а која се разликује од оне коју су имале у народно-празничној традицији и код Раблеа. Имајући у виду специфичну лепоту и живост коју такве слике дају овом роману, оне ипак остају „израз постојећег задовољства и ситости индивидуално-егоистичног човека, израз индивидуалног уживања а не свенародног тријумфа" (Бахтин 1978 :318). Михаил Бахтин у низањима хране и пића каква се могу наћи и у роману Милан Наранцић види фиксирану садашњицу (в. Бахтин 1978: 318). Таква садашњица је, управо због отргнутости од свог изворног смисла „гозбе над гозбама” у којој учествују сви након процеса борбе или рада, „без икакве симболичне ширине и универзалног смисла" (Бахтин 1978: 318). Садашњица о којој пише Михаил Бахтин остаје фиксирана и у контексту савременог тренутка. То је и разлог због којег један од наших првих реалистичких приповедача заслужује више читања из савремене књижевнотеоријске перспективе. Гурманске склоности Милана Наранџића заузимају важно место у дубљој анализи његовог лика. При томе се не сме изоставити тумачење Горана Максимовића који уочава да је „дјелатни казивач захваљујући искрености и непосредности симпатичан без обзира на сву блазираност коју носи у себи" (Максимовић 2003: 130). Тако сва његова егоистичност и бескрупулозност поступком хуморизације и вештим поигравањем комичним маскама успева да не добије изглед болног ни претераног (в. Максимовић 2003: 132). То је једна од особина приповедања Јакова Игњатовића због које његов прозни опус не губи на занимљивости ни данас.

\section{ЛИТЕРАТУРА}

Бахтин, Михаил. 1978. Стваралаштво Франсоа Раблеа и народна култура средњег века и ренесансе. Шоп, И; Вучковић, Т. (прев.). Београд: Нолит.

Ераковић, Радослав. 2016. Кюига о Јакову. Нови Сад: Филозофски факултет; Академска књига.

Иванић, Душан. 1996. Српски реализам. Нови Сад: Матица српска.

Игњатовић, Јаков. „Милан Наранџић”. Одабрана дела I. Бошков, Ж. (прир.). Нови Сад: Матица српска; Београд: Српска књижевна задруга.

Кашанин, Милан. 2004. Судбине и људи: огледи о српским писиима. Београд: Завод за уџбенике и наставна средства.

Максимовић, Горан. 2003. Тријумф смијеха. Ниш: Просвета. 
Matavulj, Simo. 1991. „Bakonja fra Brne: njegovo đakovanje i postrig”. Sabrana djela I. Zagreb: Prosvjeta.

Orsić, Srđan. 2012. „Kafanska romantika Jakova Ignjatovića”. Prosvjeta, Zagreb, br. 109.

Sanja P. Veselinović

RABELAISIAN SETS OF MEALS AND DRINKS IN THE JAKOV IGNJATOVIĆ'S NOVEL MILAN NARANDŽIĆ

\section{Summary}

The paper analyzes the functionality of Rabelaisian sets of food and drinks in the narrative structure of the novel of Serbian realism, Milan Narandzic. The author explores how food and drinks are involved in the characterization of characters and how they shape the realistic atmosphere of the novel, as well as their role in shaping the image of society from the end of the 19th century and the beginning of the 20th century. The aim of this work is to determine the substitutions that take place on the background semantic plan of the work, which show that a healthy laugh is placed in the place of toxic indignation, and a cheerful feast is placed in the place of false asceticism. It is also pointed out the differences that exist between the cheerful feast at Rabelais and Jakov Ignjatović, as well as the way in which such differences contribute to the sketching of the character of modern antihero Milan Narandžić. The results of the paper show that Jakov Ignjatovćc contributed to his inclusion in the wider context of Serbian and European literature with a skillful incorporation of feast images into the structure of his novel.

Key words: feast images, grotesque, food and drink, François Rabelais, Mihail Bakhtin 